government may dismantle Venezuelan higher education without providing opportunities for the necessary modernization of the whole education system. If current trends continue, Venezuela's complex and diverse higher education system may come to resemble the centralized Cuban system.

\section{The Immediate Future}

Chávez, who sees himself as a kind of reincarnation of Simon Bolivar and clone of Fidel Castro, his political mentor, seems to have embraced the idea of being the leader of a world revolution against capitalism. In October 2002, Chávez declared his vision for Venezuelan education in a speech before the young members of the Federación Bolivariana de Estudiantes in a Caracas theater: "No classroom in Venezuela should be without a Bolivarian student brigade."

Many people would argue with the current government's approach to higher education. But time will tell if Chávez is right. In the meantime it will be quite interesting to watch the Venezuelan higher education system going backward, from decentralization to centralized control, from diversity to homogeneity, from political and ideological pluralism to the one-dimensional fundamentalism of an indoctrination-based approach to education and, in fact, to the whole social and political system.

\section{Compromising the Charter between Higher Education and Society \\ Adrienna Kezar}

Adrienna Kezar is assistant professor of higher education at the University of Maryland-College Park. E-mail: kezar@wam.umd.edu.

$\mathrm{O}$ ver the last two decades, various social critics and leaders worldwide have noted a disturbing trend in higher education: the collective or public good, historically an important component of the charter between higher education and society, is being compromised. According to critics, higher education is forgoing its role as a social institution and is functioning increasingly as an industry with fluctuating, predominantly economic goals and market-oriented values. Increasingly, the production of workers is the primary goal. Publicly funded colleges and universities are now encouraged to privatize selected activities, becoming for-profitentities with economic engines and with private and economic as opposed to public and social goals. This shift has been called the industrial or entrepreneurial model.
Critics are concerned that the current charter encourages ethical and educational compromises that are potentially harmful to higher education and the general public, especially as it relates to the historic mission of fostering democracy and important values such as equality, academic freedom, or the pursuit of knowledge. Social commentators note that this orientation to the market and economic goals is a worldwide phenomenon and even more prevalent within developing countries where economic advancement has become the cornerstone of political and educational agendas.

\section{Cause for Concern}

Although the aims of higher education have shifted over time, critics worry that this dramatic alteration is taking place seemingly without dialogue or awareness among the major constituent groups. Why does a discussion of the charter between higher education and society matter? Because the social charter is the foundation of higher education institutions' missions and values and it affects choices made by all individuals in the system of higher education from policymakers to parents to faculty to students. For example, if policymakers and the general public are not clear about why investment in higher education matters and do not appreciate the social and public benefits, other public policy priorities may end up gaining more support than higher education.

\section{Empirical Evidence}

Recently I conducted a meta-analysis of the research on these trends toward privatization and commercialization (industrial model) to examine the broad claims by social critics. In short, the evidence does support claims that some sectors of higher education in the United States have become industrialized, particularly research and comprehensive institutions and institutions with Division I athletic teams.

Studies document that corporate language and practices have replaced traditional academic administration in which educational values such as truth, equity, autonomy, and mission are central to decision making. This shift in language and values has translated into many new approaches such as outsourcing, restructuring, and responsibilitycentered budgeting. Research privatization is growing yearly at exponential levels. Several scholars have traced the increasing vocationalization of the curriculum and disenfranchisement of faculty, as evidenced by the declining number of full-time and tenure-track lines and growing numbers of part-time and contract faculty. 
Costs/Benefits

While these shifts have occurred, studies of costs and benefits show virtually no positive outcomes from the corporatization of management. Privatization and commercialization of research has been demonstrated to have a host of negative outcomes including: a decline in basic research; a reduction in the importance of teaching on many campuses; conflicts of interest, such as faculty having financial interests in research that has affected the integrity of scholarship; and loss of community intellectual property. The disenfranchisement of faculty (through the growth in part-time and contract faculty) also has led to cutbacks in student advising, limited student-faculty contact, decreased involvement in campus governance, among other outcomes. The vocationalized curriculum and weakened teaching have resulted in a decline in the humanities and nonapplied social science fields as well as in the holistic and critical thinking pedagogies that have been demonstrated to be essential for citizenship education and the education of leaders. Yet, there are also benefits from the shift to the industrial model. The privatization of research has increased funds for research, improved laboratories and facilities, and provided additional funding for students. The growth of vocational fields and distance learning has provided access to higher education to greater numbers of individuals.

\section{The disenfranchisement of faculty (through the growth in part-time and contract faculty) also has led to cut- backs in student advising, limited stu- dent-faculty contact, decreased involvement in campus governance.}

\section{Lost Promise}

Although proponents of the industrial model claim it will save money, expenses and tuition have risen during the period that this model has been in place. In the late 1990s, a commission was created by the U.S. Department of Education to investigate the rising cost of higher education. The commission found that in the 20 years between 1976 and 1996, the average tuition at public universities increased at a rate well above inflation, from $\$ 642$ to $\$ 3,151$, and the average tuition at private universities increased from $\$ 2,881$ to $\$ 15,581$. Tuition at public two-year colleges, the least expensive of all types of institutions, increased from an average of $\$ 245$ to $\$ 1,245$ during this period. This occurred simultaneously as federal policy shifted the burden for paying for college to students and their families by awarding fewer and smaller Pell grants and increasing the available loans. Many of the proclaimed benefits of the new industrial model are simply not being realized.

\section{Questions for Leaders}

Because the industrial model and new charter affect the traditional social and public purposes of higher education and the known costs appear to outweigh the benefits, it is important for leaders worldwide to engage in discussion on the issues. Dialogue about the charter is long overdue, and it is time to develop a new vision of higher education's mission and values. Leaders need to deal with a number of questions.

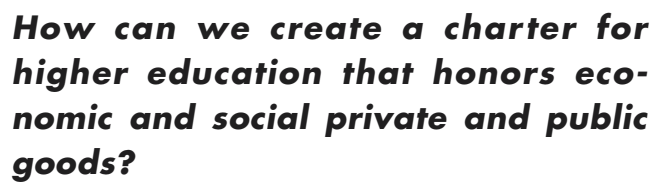

To what degree should higher education adapt to market forces and which historic functions and longer-term public interests should it retain? How can we create a charter for higher education that honors economic and social private and public goods?

To what degree should higher education become private and what would be the impact of this shift? Is public higher education part of the state or is it independent? What type of autonomy or regulation should be practiced?

How can we conceive of private and public goods in complex ways that will sustain the social role of higher education? It is important not to dichotomize public and private or social and economic interests. Studies illustrate how private goods benefit the public in the form of higher salaries and stability of employment, improved health of college graduates, and better consumer decision making among college graduates.

How can we reconcile market-oriented values with traditional academic values? For example, academic freedom, access and equity, excellence and integrity, and dedication to inquiry are important elements in the effort to fulfill the public mission. Which values should be upheld and reinforced as higher education partners with other groups representing different value systems? How can these values be maintained? 